\title{
CSF1R copy number changes, point mutations, and RNA and protein overexpression in renal cell carcinomas
}

\author{
Maria J Soares ${ }^{1}$, Mafalda Pinto ${ }^{1}$, Rui Henrique ${ }^{2,3}$, Joana Vieira ${ }^{1}$, Nuno Cerveira ${ }^{1}$, \\ Ana Peixoto $^{1}$, Ana T Martins ${ }^{2}$, Jorge Oliveira ${ }^{4}$, Carmen Jerónimo ${ }^{1,3,5}$ and Manuel R Teixeira ${ }^{1,3}$ \\ ${ }^{1}$ Department of Genetics, Portuguese Oncology Institute, Porto, Portugal; ${ }^{2}$ Department of Pathology, \\ Portuguese Oncology Institute, Porto, Portugal; ${ }^{3}$ Institute of Biomedical Sciences (ICBAS), University of \\ Porto, Porto, Portugal; ${ }^{4}$ Department of Urology, Portuguese Oncology Institute, Porto, Portugal and ${ }^{5}$ Fernando \\ Pessoa University School of Health Sciences, Porto, Portugal
}

\begin{abstract}
Renal cell carcinomas comprise a heterogeneous group of tumors. Of these, $80 \%$ are clear cell renal cell carcinomas, which are characterized by loss of $3 p$, often with concomitant gain of $5 q 22 q$ ter. Although VHL is considered the main target gene of the $3 p$ deletions, none has been identified as the relevant target gene for the 5q gain. We have studied 75 consecutive kidney tumors and paired normal kidney samples to evaluate at the genomic and expression levels the tyrosine kinase genes CSF1R and PDGFRB as potential targets in this region. Our findings show that RNA expression of CSF1R, but not of PDGFRB, was significantly higher in clear cell renal cell carcinomas than in normal tissue samples, something that was corroborated at the protein level by immunohistochemistry. The CSF1R staining pattern in clear cell renal cell carcinomas was clearly different from that observed in other renal cell carcinomas, suggesting its potential usefulness in differential diagnosis. FISH analysis demonstrated whole chromosomal gain and relative CSF1RIPDGFRB copy number gain in clear cell renal cell carcinomas, which might contribute to CSF1R overexpression. Finally, one polymorphism and two novel mutations were identified in CSF1R in clear cell renal cell carcinoma patients. Our data allow us to conclude that CSF1R plays a relevant role in clear cell renal cell carcinoma carcinogenesis and raise the possibility that CSF1R may represent a future valuable therapeutic target in these patients.
\end{abstract}

Modern Pathology (2009) 22, 744-752; doi:10.1038/modpathol.2009.43; published online 17 April 2009

Keywords: renal cell carcinoma; CSF1R oncogene; mutation; overexpression

Renal cell carcinomas comprise a heterogeneous group of tumors that represent about $3 \%$ of all malignancies in adults in the Western countries. ${ }^{1}$ Clear cell renal cell carcinomas, which represent about $80 \%$ of all kidney tumors, are characterized by the loss of the short arm of chromosome 3 (3p), often with a concomitant gain of $5 q 22$ qter as the result of an unbalanced 3p;5q translocation. ${ }^{2}$ Several genes have been presented as the targets of the $3 p$ deletions seen in this tumor type, with emphasis for $V H L(3 p 25 \sim$ p26). In fact, germline mutations of VHL underlie the von Hippel-Lindau syndrome (which includes clear cell renal cell carcinoma as one of its features), whereas somatic inactivation of this gene has been demonstrated in the great

Correspondence: Professor MR Teixeira, MD, PhD, Department of Genetics, Portuguese Oncology Institute, Rua Dr António Bernardino de Almeida, 4200-072 Porto, Portugal.

E-mail: manuel.teixeira@ipoporto.min-saude.pt

Received 1 October 2008; revised 24 December 2008; accepted 2 January 2009; published online 17 April 2009 majority of sporadic clear cell renal cell carcinomas. ${ }^{3,4}$ On the other hand, no target genes have been identified for the 5q22qter gain, the second most common copy number change in clear cell renal cell carcinomas. ${ }^{2,5}$

The colony-stimulating factor-1 receptor (CSF1R) gene located in $5 \mathrm{q} 33$ is a potential target for this chromosomal gain in clear cell renal cell carcinomas. CSF1R is a transmembrane tyrosine kinase receptor and the CSF1R/CSF1 receptor/ligand complex has essential physiological functions in monocyte and macrophage differentiation, embryonic implantation, placental development, and lactogenic differentiation of the human breast. ${ }^{6}$ Codons 301 and 969 located in CSF1R exons 7 and 22, respectively, have been shown to be mutated in hematological malignancies, with mutations in codon 301 being associated with neoplastic transformation through constitutive activation of the tyrosine kinase receptor ${ }^{7}$ and deletions or mutations in codon 969 disrupting its negative regulatory activity. ${ }^{8,9}$ Furthermore, a novel fusion gene between 
$R B M 6$ and $C S F 1 R$ generated by a $\mathrm{t}(3 ; 5)(\mathrm{p} 21 ; \mathrm{q} 33)$ has been identified in acute megakaryoblastic leukemia, coding for a chimeric RBM6-CSF1R protein that confers interleukin-3 independent growth. ${ }^{10}$ Molecular cytogenetic studies of in vitro models of clear cell renal cell carcinoma have shown frequent $C S F 1 R$ copy number gain, ${ }^{5,11}$ but its role in renal carcinogenesis is still unexplored.

In this work, we aimed to study a relatively large series of kidney tumors for $C S F 1 R$ expression both at the mRNA and protein levels, to determine the relationship between $C S F 1 R$ expression and genomic copy number changes, as well as to look for CSF1R point mutations in exons 7 and 22. As the plateletderived growth factor receptor beta (PDGFRB) gene belongs to the same gene family as CSF1R and is located nearby in $5 q 31 \sim 32$, we also aimed to evaluate its expression in renal cell tumors for comparison.

\section{Materials and methods}

\section{Patient Data}

A consecutive series of 75 kidney tumors diagnosed at the Portuguese Oncology Institute (Porto, Portugal) in 2004 and 2005 were studied. The institutional review board approved the project and patients were enrolled after informed consent. All patients underwent partial or radical nephrectomy before any other kind of treatment. Histologically, 41 were classified as clear cell renal cell carcinoma, 13 as chromophobe renal cell carcinoma, 5 as papillary renal cell carcinoma, 8 as oncocytomas, 2 as unclassifiable renal cell carcinoma (consisting of an admixture of areas of clear cell RCC, papillary RCC, and clear cell lined papillae), and 6 as tumors of other than renal cell origin (Table 1). For control purposes, paired nonneoplastic renal tissue distant from the tumor was obtained when possible. Tissue samples intended for genetic analysis were snap frozen immediately after surgery and stored at $-80^{\circ} \mathrm{C}$. Five-micrometer thick sections were then cut in a cryostat for molecular studies, and at every 15 cuts were microscopically checked for normal tissue and tumor tissue content. According to routine diagnostic procedures, representative tumor and normal tissues were formalin fixed and subsequently processed for paraffin embedding. Sections were cut and H\&E stained for histopathological evaluation. These procedures comprised the diagnosis, grading, and pathological staging. Additional $5 \mu \mathrm{m}$ thick sections of paraffin-embedded tissue were cut for immunohistochemical and FISH analyses.

\section{Nucleic Acids Extraction and cDNA Synthesis}

Genomic DNA was extracted from tumor and normal tissue using a standard technique comprising overnight digestion with proteinase $\mathrm{K}(20 \mathrm{mg} / \mathrm{ml})$ in the presence of $10 \%$ SDS at $55^{\circ} \mathrm{C}$, followed by phenol- chloroform extraction and precipitation with $100 \%$ ethanol. ${ }^{12}$

Total RNA was extracted from all samples using the FastRNA Green Kit (Qbiogene, Carlsbad, CA, USA) for $45 \mathrm{~s}$, with a speed rating of 6.0 in a FastPrep FP120 Instrument (Qbiogene). Reverse transcription was performed with the SuperScript III First-Strand Synthesis System for RT-PCR (Invitrogen, Carlsbad, CA, USA), following the manufacturer's instructions.

\section{CSF1R and PDGFRB mRNA Quantification}

Quantification of mRNA of the CSF1R and PDGFRB genes was performed by real-time RT-PCR using TaqMan probes on an ABI PRISM 7000 Sequence Detection System (Applied Biosystems, Foster City, CA, USA). Primers and probes for both genes, as well as for the endogenous control gene HPRT, were purchased as a predeveloped assay reagent from Applied Biosystems.

PCR reactions were performed in a $20 \mu \mathrm{l}$ volume reaction containing $9 \mu \mathrm{l}$ of synthesized cDNA, $10 \mu \mathrm{l}$ of TaqMan universal master mix (Applied Biosystems), and $1 \mu \mathrm{l}$ of primer and probe set. PCR was performed in separate wells for each primer/probe set and each sample was run in triplicate. PCR parameters were as follows: $50^{\circ} \mathrm{C}$ for $2 \mathrm{~min}, 95^{\circ} \mathrm{C}$ for $10 \mathrm{~min}$, followed by 50 cycles at $95^{\circ} \mathrm{C}$ for $15 \mathrm{~s}$ and $60^{\circ} \mathrm{C}$ for $1 \mathrm{~min}$. Each plate included multiple negative controls consisting of bidistilled water, as well as serial dilutions of a positive control to make the standard curve.

To determine the relative mRNA expression levels of both CSF1R and PDGFRB for each sample, the expression value of the target gene was divided by the HPRT expression value to obtain a normalized target/internal reference ratio. This value was then divided by the average CSF1R or PDGFRB expression value of the normal renal tissue samples normalized against the average HPRT value, to obtain the relative expression level of each target gene in tumors as compared with normal tissue. ${ }^{3,14}$ Overexpression of $C S F 1 R$ was defined as a relative expression level higher than 7.35 (mean +3 s.d. in normal tissue), whereas overexpression of PDGFRB was defined as a relative expression level higher than 146.82 (mean + 3s.d. in normal tissue).

\section{Immunohistochemistry}

The tissue slides were deparaffinized by rinsing with xylol and rehydrated by passing through graded alcohols (absolute ethanol, 90, 80, 70, 50\%). Endogenous peroxidase activity was blocked by incubating the slides for $20 \mathrm{~min}$ in $0.3 \% \mathrm{H}_{2} \mathrm{O}_{2}$ in a $5 \%$ methanol solution. After washing the slides in water and PBS/ $0.05 \%$ Tween 20 solution, they were incubated with normal serum (Vectastain Universal Elite ABC Kit; Vector Laboratories, Burlingame, CA, USA) 1/100 in PBS-bovine serum albumine (BSA) $10 \%$ at room 
Table 1 RNA and protein expression and genomic data on the CSF1R and PDGFRB genes in 75 kidney tumors

\begin{tabular}{|c|c|c|c|c|c|c|}
\hline Histology & Sample & $\begin{array}{l}q R T-P C R \\
\text { CSF1R }\end{array}$ & $\begin{array}{l}q R T-P C R \\
\text { PDGFRB }\end{array}$ & $\begin{array}{l}I H C \\
\text { CSF1R }\end{array}$ & $\begin{array}{l}\text { FISH }{ }^{\mathrm{a}, \mathrm{b}} \\
\text { CSF1R/PDGFRB }\end{array}$ & $\begin{array}{l}\text { Mutations } \\
\text { CSF1R }\end{array}$ \\
\hline Clear cell RCC $(n=41)$ & $\begin{array}{l}\text { RT } 128 \\
\text { RT } 130 \\
\text { RT } 131 \\
\text { RT } 132 \\
\text { RT } 133 \\
\text { RT } 137 \\
\text { RT } 138 \\
\text { RT } 140 \\
\text { RT } 142 \\
\text { RT } 143 \\
\text { RT } 144 \\
\text { RT } 150 \\
\text { RT } 151 \\
\text { RT } 152 \\
\text { RT } 154 \\
\text { RT } 155 \\
\text { RT } 157^{\text {c }} \\
\text { RT } 158 \\
\text { RT } 159 \\
\text { RT } 160 \\
\text { RT } 161 \\
\text { RT } 163 \\
\text { RT } 164 \\
\text { RT } 165 \\
\text { RT } 166 \\
\text { RT } 168 \\
\text { RT } 170 \\
\text { RT } 172 \\
\text { RT } 173 \\
\text { RT } 174 \\
\text { RT } 177 \\
\text { RT } 180 \\
\text { RT } 181 \\
\text { RT } 186 \\
\text { RT } 188 \\
\text { RT } 190 \\
\text { RT } 191 \\
\text { RT } 197^{\text {c }} \\
\text { RT } 199 \\
\text { RT } 200 \\
\text { RT } 201\end{array}$ & $\begin{array}{c}18.60 \\
27.61 \\
16.15 \\
3.34 \\
4.52 \\
1.78 \\
9.05 \\
13.24 \\
4.66 \\
1.11 \\
18.92 \\
3.19 \\
4.53 \\
3.49 \\
31.58 \\
11.75 \\
9.08 \\
20.07 \\
8.82 \\
5.24 \\
5.96 \\
2.66 \\
13.74 \\
5.5 \\
6.92 \\
10.89 \\
5.97 \\
12.00 \\
7.36 \\
1.54 \\
18.39 \\
\mathrm{~N} A \\
1.93 \\
14.02 \\
10.10 \\
35.03 \\
19.64 \\
\mathrm{~N} A \\
4.24 \\
11.66 \\
5.20\end{array}$ & $\begin{array}{c}2.50^{-3} \\
3.54^{-2} \\
9.60^{-3} \\
2.00^{-4} \\
9.00^{-4} \\
8.40^{-3} \\
1.12^{-1} \\
1.85^{-2} \\
3.00^{-4} \\
2.00^{-4} \\
6.20^{-3} \\
5.27 \\
5.16 \\
1.00^{-4} \\
1.72^{4} \\
4.19 \\
1.83^{4} \\
6.79^{4} \\
2.90 \\
\mathrm{NA}^{-19} \\
\mathrm{NA}^{-1} \\
2.68^{-1} \\
2.35 \\
\mathrm{NA}^{-3} \\
4.56 \\
7.76^{-1} \\
4.25^{-1} \\
1.06 \\
1.94 \\
9.27^{-1} \\
1.51 \\
\mathrm{NA}^{-1} \\
4.72 \\
3.30 \\
1.60 \\
8.59 \\
6.15 \\
\mathrm{NA}^{-1.10} \\
2.98^{-1}\end{array}$ & $\begin{array}{l}\text { Positive } \\
\text { Positive } \\
\text { Positive } \\
\text { Positive } \\
\text { Positive } \\
\text { Positive } \\
\text { Positive } \\
\text { Positive } \\
\text { Positive } \\
\text { Positive } \\
\text { Positive } \\
\text { Positive } \\
\text { Positive } \\
\text { Positive } \\
\text { Positive } \\
\text { Positive } \\
\text { Positive } \\
\text { Positive } \\
\text { Positive } \\
\text { Positive } \\
\text { Positive } \\
\text { Positive } \\
\text { Positive } \\
\text { Positive } \\
\text { Positive } \\
\text { Positive } \\
\text { Positive } \\
\text { Positive } \\
\text { Positive } \\
\text { Positive } \\
\text { Positive } \\
\text { Positive } \\
\text { Positive } \\
\text { Positive } \\
\text { Positive } \\
\text { Positive } \\
\text { Positive } \\
\text { Positive } \\
\text { Positive } \\
\text { Positive }\end{array}$ & $\begin{array}{l}\text { Normal } \\
(3: 3) / 4: 4 \\
\text { Normal } \\
3: 2 / 6: 4 \\
\text { Normal } \\
3: 2 \\
\text { Normal } \\
\text { Normal } \\
4: 2 \\
3: 2 / 3: 3 / 4: 4 \\
\text { Normal } \\
4: 4 / 3: 3 \\
4: 4 / 5: 5 / 3: 3 \\
3: 2 / 3: 3 / 4: 2 / 4: 4 \\
3: 2 / 6: 4 \\
3: 3 / 4: 4 / 6: 6 \\
3: 3 / 3: 2 \\
3: 3 / 3: 2 \\
4: 4 / 3: 2 \\
\text { Normal } \\
3: 3 / 4: 4 \\
\text { Normal } \\
3: 3 \\
\text { Normal } \\
4: 3 / 3: 3 / 4: 2 / 3: 2 \\
\text { Normal } \\
3: 2 / 3: 3 \\
\text { Normal } \\
4: 4 / 3: 3 \\
3: 3 \\
\text { Normal } \\
\text { Normal } \\
4: 4 / 3: 3 \\
\text { NA } \\
\text { Normal } \\
3: 3 / 4: 4 \\
3: 3 / 5: 5 / 4: 4 / 6: 6 \\
3: 2 \\
\text { Normal } \\
3: 3 \\
\text { Normal } \\
\end{array}$ & $\begin{array}{l}\text { Normal } \\
\text { Normal } \\
\text { Normal } \\
\text { Normal } \\
\text { Normal } \\
\text { Normal } \\
\text { Normal } \\
\text { Normal } \\
\text { c.12C }>\text { T } \\
\text { Normal } \\
\text { Normal } \\
\text { c.908T }>\text { C } \\
\text { Normal } \\
\text { Normal } \\
\text { c.2799T }>\text { C } \\
\text { Normal } \\
\text { Normal } \\
\text { Normal } \\
\text { Normal } \\
\text { Normal } \\
\text { Normal } \\
\text { Normal } \\
\text { Normal } \\
\text { Normal } \\
\text { Normal } \\
\text { Normal } \\
\text { Normal } \\
\text { Normal } \\
\text { Normal } \\
\text { Normal } \\
\text { Normal } \\
\text { Normal } \\
\text { Normal } \\
\text { Normal } \\
\text { Normal } \\
\text { Normal } \\
\text { Normal } \\
\text { Normal } \\
\text { Normal } \\
\text { Normal } \\
\text { Normal }\end{array}$ \\
\hline Chromophobe RCC $(n=13)$ & $\begin{array}{ll}\text { RT } & 129 \\
\text { RT } & 134 \\
\text { RT } & 136 \\
\text { RT } & 153 \\
\text { RT } & 156 \\
\text { RT } & 169 \\
\text { RT } & 175 \\
\text { RT } & 183 \\
\text { RT } & 192 \\
\text { RT } & 193 \\
\text { RT } & 194 \\
\text { RT } & 195 \\
\text { RT } & 196\end{array}$ & $\begin{array}{c}0.11 \\
0.21 \\
0.15 \\
0.08 \\
2.51 \\
10.50 \\
0.32 \\
0.57 \\
0.01 \\
1.07 \\
0.04 \\
\text { NA } \\
\text { NA }\end{array}$ & $\begin{array}{l}\text { ND } \\
\text { ND } \\
\text { ND } \\
\text { ND } \\
\text { ND } \\
\text { ND } \\
\text { ND } \\
\text { ND } \\
\text { ND } \\
\text { ND } \\
\text { ND } \\
\text { ND }\end{array}$ & $\begin{array}{l}\text { Negative } \\
\text { Negative } \\
\text { Negative } \\
\text { Negative } \\
\text { Negative } \\
\text { Negative } \\
\text { Negative } \\
\text { Negative } \\
\text { Negative } \\
\text { Negative } \\
\text { Focal } \\
\text { Focal } \\
\text { Negative }\end{array}$ & $\begin{array}{l}4: 4 \\
4: 4 / 8: 8 \\
1: 1 \\
4: 4 / 3: 3 \\
3: 3 / 4: 4 / 6: 6 \\
\text { Normal } \\
\text { Normal } \\
\text { NA } \\
3: 3 / 4: 4 / 6: 6 \\
\text { Normal } \\
4: 4 \\
\text { NA } \\
\text { Normal }\end{array}$ & $\begin{array}{l}\text { ND } \\
\text { ND } \\
\text { ND } \\
\text { ND } \\
\text { ND } \\
\text { ND } \\
\text { ND } \\
\text { ND } \\
\text { ND } \\
\text { ND } \\
\text { ND } \\
\text { ND } \\
\text { ND }\end{array}$ \\
\hline Papillary RCC $(n=5)$ & $\begin{array}{ll}\text { RT } 147 \\
\text { RT } 179 \\
\text { RT } 182 \\
\text { RT } 187 \\
\text { RT } 198\end{array}$ & $\begin{array}{c}72.03 \\
\text { NA } \\
1.16 \\
7.04 \\
2.58\end{array}$ & $\begin{array}{l}\text { ND } \\
\text { ND } \\
\text { ND } \\
\text { ND } \\
\text { ND }\end{array}$ & $\begin{array}{l}\text { Positive }^{\mathrm{d}} \\
\text { Negative } \\
\text { Negative } \\
\text { Focal } \\
\text { Positive }^{\mathrm{d}}\end{array}$ & $\begin{array}{l}\text { Normal } \\
\text { Normal } \\
\text { Normal } \\
\text { Normal } \\
\text { Normal }\end{array}$ & $\begin{array}{l}\text { ND } \\
\text { ND } \\
\text { ND } \\
\text { ND } \\
\text { ND }\end{array}$ \\
\hline Unclassifiable RCC $(n=2)$ & $\begin{array}{ll}\text { RT } 139 \\
\text { RT } 149\end{array}$ & $\begin{array}{l}2.67 \\
\text { NA }\end{array}$ & $\begin{array}{l}\mathrm{ND} \\
\mathrm{ND}\end{array}$ & $\begin{array}{l}\text { Positive } \\
\text { Positive }^{\mathrm{d}}\end{array}$ & $\begin{array}{l}\text { Normal } \\
\text { Normal }\end{array}$ & $\begin{array}{l}\text { ND } \\
\text { ND }\end{array}$ \\
\hline Oncocytomas $(n=8)$ & $\begin{array}{l}\text { RT } 135 \\
\text { RT } 141 \\
\text { RT } 145 \\
\text { RT } 146 \\
\text { RT148 }\end{array}$ & $\begin{array}{l}0.04 \\
1.93 \\
0.03 \\
\text { NA } \\
\text { NA }\end{array}$ & $\begin{array}{l}\text { ND } \\
\text { ND } \\
\text { ND } \\
\text { ND } \\
\text { ND }\end{array}$ & $\begin{array}{l}\text { ND } \\
\text { ND } \\
\text { ND } \\
\text { ND } \\
\text { ND }\end{array}$ & $\begin{array}{l}\text { ND } \\
\text { ND } \\
\text { ND } \\
\text { ND } \\
\text { ND }\end{array}$ & $\begin{array}{l}\text { ND } \\
\text { ND } \\
\text { ND } \\
\text { ND } \\
\text { ND }\end{array}$ \\
\hline
\end{tabular}


Table 1 Continued

\begin{tabular}{|c|c|c|c|c|c|c|}
\hline Histology & Sample & $\begin{array}{c}q R T-P C R \\
\text { CSF1R }\end{array}$ & $\begin{array}{l}q R T-P C R \\
\text { PDGFRB }\end{array}$ & $\begin{array}{l}\text { IHC } \\
\text { CSF1R }\end{array}$ & $\begin{array}{l}F I S H^{\mathrm{a}, \mathrm{b}} \\
\text { CSF1R/PDGFRB }\end{array}$ & $\begin{array}{l}\text { Mutations } \\
\text { CSF1R }\end{array}$ \\
\hline & RT 162 & 0.23 & ND & ND & ND & ND \\
\hline & RT 171 & 0.03 & ND & ND & ND & ND \\
\hline & RT 178 & 0.79 & ND & ND & ND & ND \\
\hline \multirow[t]{3}{*}{ Urothelial carcinoma $(n=3)$} & RT 167 & 1.58 & ND & ND & ND & ND \\
\hline & RT 184 & 0.58 & ND & ND & ND & ND \\
\hline & RT 189 & 1.29 & ND & ND & ND & ND \\
\hline Leiomyosarcoma & RT 126 & 0.67 & ND & ND & ND & ND \\
\hline Follicular lymphoma & RT 127 & 13.76 & ND & ND & ND & ND \\
\hline Angiomyolipoma & RT 185 & 4.53 & ND & ND & ND & ND \\
\hline
\end{tabular}

RCC, renal cell carcinoma; NA, sample not analyzable; ND, not determined.

${ }^{\mathrm{a}}$ Number of copies of CSF1R/PDGFRB: number of copies of 5p15.2 (LSI D5S23. D5S721).

${ }^{\mathrm{b}}$ Most representative cell population indicated at first.

${ }^{\mathrm{c}}$ Multilocular cystic renal cell carcinoma (variant of clear cell renal cell carcinoma).

${ }^{\mathrm{d}}$ Cytoplasmatic and membrane immunoreactivity.

temperature for $30 \mathrm{~min}$ in a humid chamber. After incubation, the primary antibody (rabbit polyclonal antibody; c-Fms/CSF-1R: sc-692; Santa Cruz Biotechnology, Santa Cruz, CA, USA) was added at a dilution of 1:200 in PBS-BSA $10 \%$, and the slides were incubated overnight at $4^{\circ} \mathrm{C}$ in a humid chamber. The slides were then rinsed in PBS $/ 0.05 \%$ Tween 20 solution and bound antibody was detected by applying biotinylated secondary antibody and ABC reagent from the Vectastain Universal Elite ABC kit. The slides were washed in PBS and incubated for $7 \mathrm{~min}$ in $3^{\prime}, 3$-diaminobenzidine (DAB; SigmaAldrich, Steinheim, Germany) in a solution of $50 \mathrm{ml}$ PBS-BSA $1 \%+50 \mu \mathrm{l} \mathrm{H}_{2} \mathrm{O}_{2}$. Counterstaining was then performed with hematoxylin (Harris Modified Hematoxylin Stain; Fisher Scientific, Fair Lawn, NJ, USA) for $30 \mathrm{~s}$ and washed for $10 \mathrm{~min}$ in $\mathrm{H}_{2} \mathrm{O}$. Slides were mounted with Entellan (Merck KGaA, Darmstadt, Germany). A placenta sample was used as positive control. Sections were scored as negative, focal $(<25 \%)$, or diffuse staining.

\section{Fluorescent In Situ Hybridization}

Five-micrometer thick sections from a representative paraffin-embedded block of each tumor were cut onto SuperFrost Plus Adhesion slides (Menzel-Glaser, Braunschweig, Germany). Slides were deparaffinized in two series of xylol followed by two series of ethanol ( 5 min each), rinsed in $2 \times$ SSC, and placed in a solution of NaSCN $1 \mathrm{M}$ at $80^{\circ} \mathrm{C}$ for 20 min (Merck $\mathrm{KGaA}$ ). The tissue was then digested with $6 \mathrm{mg} / \mathrm{ml}$ pepsin (Sigma-Aldrich) for $20 \mathrm{~min}$ at $37^{\circ} \mathrm{C}$, after which slides were rinsed in $2 \times$ SSC and dehydrated in a series of ethanol. A dual-color probe targeting 5p15.2 (control) labeled with SpectrumGreen and the CSF1R and PDGFRB genes on $5 \mathrm{q}$ labeled with SpectrumOrange (Vysis LSI; Abbott Laboratories, IL, USA) was used for each sample. Slides were then placed in a Hybrite denaturation/hybridization system (Abbott Laboratories) and codenatured at $80^{\circ} \mathrm{C}$ for $8 \mathrm{~min}$. Hybridization took place for $18 \mathrm{~h}$ at $37^{\circ} \mathrm{C}$ followed by posthybridization washes in $2 \times \mathrm{SSC} /$ $0.5 \%$ Igepal (Sigma-Aldrich) at $73^{\circ} \mathrm{C}$ for $5 \mathrm{~min}$ and $2 \times \mathrm{SSC} / 0.1 \%$ Igepal at room temperature for $3 \mathrm{~min}$. Slides were counterstained with DAPI (Vector Laboratories). The cut-off value for FISH scoring was calculated using the Microsoft Excel inverse function as described by Wolff et al ${ }^{15}$ after analyzing 100 cells from each of 10 normal tissue samples $(99 \%$ confidence level). The cutoff for amplification was a $5 q / 5 p$ copy number ratio equal or above 2.2 .

\section{Mutation Analysis}

The mutation hotspots in exons 7 and 22 of the CSF1R gene were screened by direct sequencing in an automatic DNA sequencer ABI PRISM $310^{\mathrm{TM}}$ Genetic Analyser (Applied Biosystems), using primers described by Abu-Duhier et al. ${ }^{16}$ Data analysis was performed with Sequencing Analysis Software (version 5.2; Applied Biosystems).

\section{Statistical Analysis}

Statistical calculations were performed with SPSS for Windows version 15.0 (SPSS, Chicago, IL, USA). The Mann-Whitney $U$-test was used as nonparametric test for unpaired samples to assess the significance of differences between histological groups with respect to gene expression and to evaluate the relationship between gene copy number and gene expression. All two-tailed $P$ values less than 0.05 were considered significant.

\section{Results}

\section{CSF1R and PDGFRB Expressions by Quantitative RT-PCR}

All 75 kidney tumors and paired normal kidney samples were analyzed for CSF1R RNA expression by 
quantitative RT-PCR (Table 1). Increased CSF1R RNA expression was observed in kidney tumors when compared with normal kidney tissue samples $\left(P=3.19^{-9}\right)$. When considering the histological subtypes, the level of CSF1R RNA expression was significantly higher in clear cell renal cell carcinomas compared with the remaining tumors altogether $\left(P=1.00^{-7}\right)$ and with most of the other tumor types individually (all but papillary renal cell carcinomas; Figure 1).

Significant CSF1R RNA overexpression (expression level higher than mean +3 s.d. of that in normal tissue) was seen in 21 of the $41(51 \%)$ patients with clear cell renal cell carcinoma, in one of five $(20 \%)$ patients with papillary renal cell carcinoma, in one of $13(8 \%)$ patients with chromophobe renal cell carcinoma and in a renal follicular lymphoma. No altered $C S F 1 R$ expression was observed in the two unclassifiable renal cell carcinomas, in the eight oncocytomas, or in the remaining five tumors of other than renal cell origin.

For PDGFRB RNA expression, all 41 clear cell renal cell carcinomas and corresponding normal kidney samples were analyzed (Table 1). PBGFRB RNA overexpression was seen in $3(7.3 \%)$ of the 41 clear cell renal cell carcinomas, but no statistically significant differences were found between this carcinoma subtype and paired nonneoplastic tissue.

\section{CSF1R Protein Expression by Immunohistochemistry}

We examined all 61 renal cell carcinomas (Table 1) and 10 samples of normal tissue by immunohistochemical analysis targeting CSF1R (Figure 2). Strong and diffuse membrane CSF1R immunoreactivity was observed in all 41 clear cell renal cell

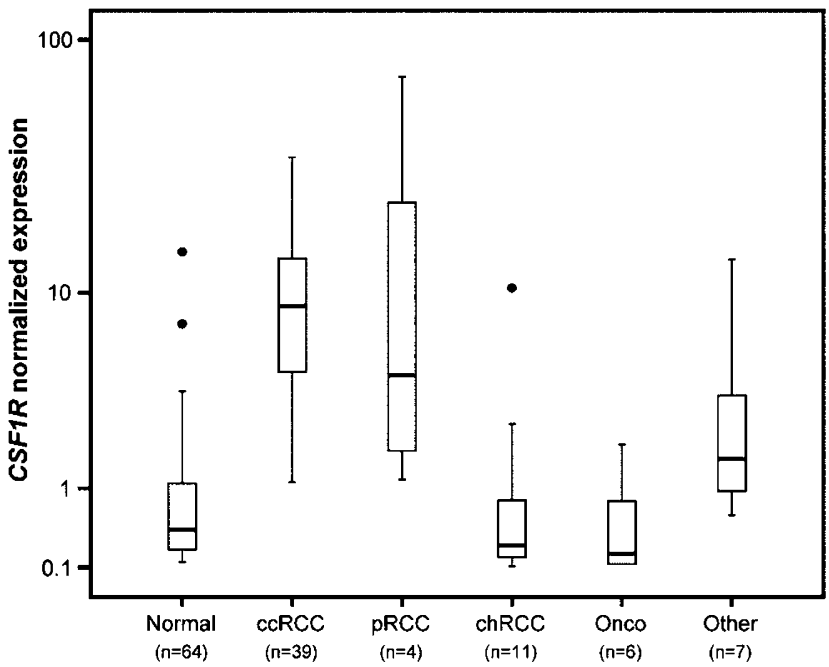

Figure 1 CSF1R RNA expression by real-time PCR in kidney tumors and in nonneoplastic tissue (ccRCC: clear cell renal cell carcinoma; pRCC: papillary renal cell carcinoma; chRCC: chromophobe renal cell carcinoma; onco: oncocytoma; other: non renal cell carcinoma tumors; normal: normal kidney tissue). RNA overexpression was detected in most clear cell renal cell carcinomas and occasionally in other renal cell carcinomas (black dots indicate outliers). carcinomas. Two of the five papillary renal cell carcinomas (one of them with RNA overexpression) showed diffuse cytoplasmatic and membrane CSF1R immunoreactivity, whereas one presented
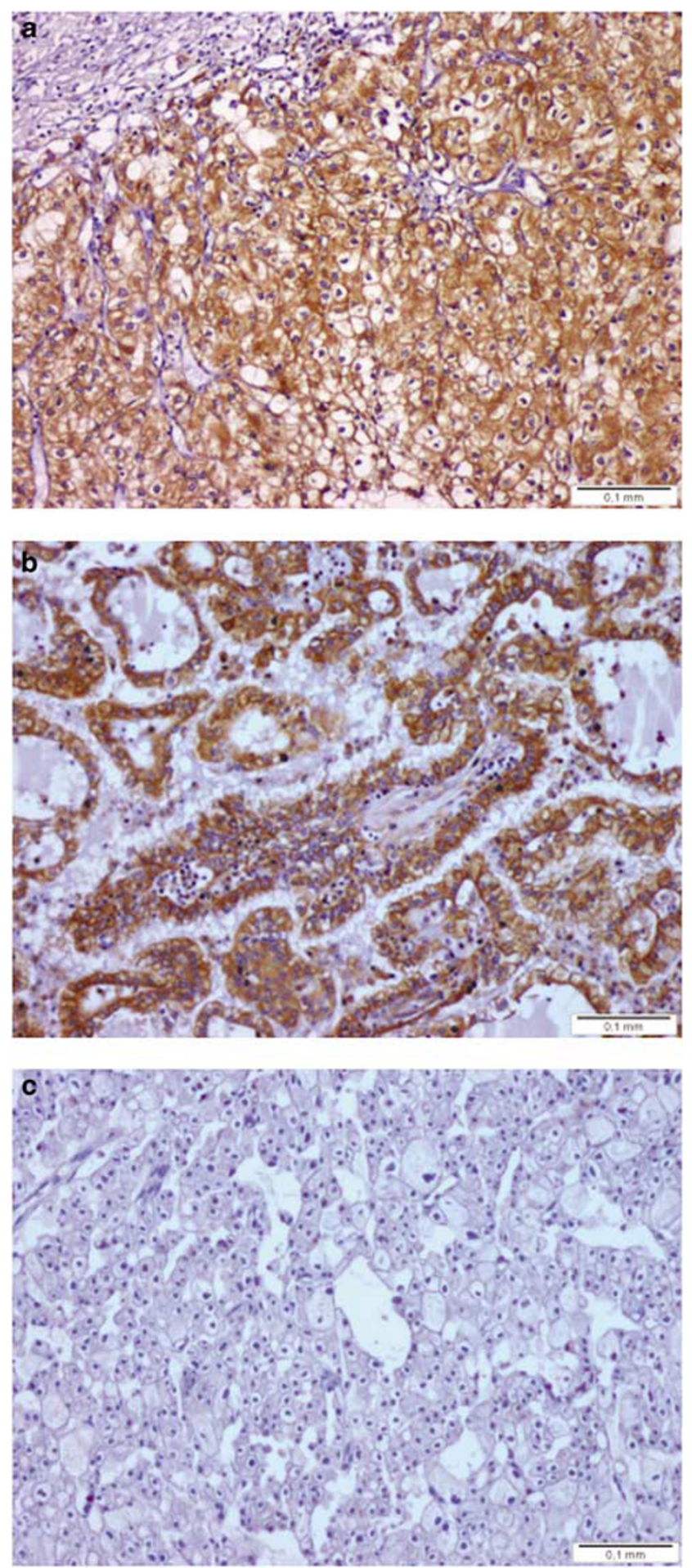

Figure 2 CSF1R protein expression by immunohistochemical analysis. (a) Clear cell renal cell carcinoma with diffuse membrane CSF1R immunoreactivity and its absence in stromal cells. (b) Papillary renal cell carcinoma with diffuse membrane and cytoplasmatic CSF1R immunoreactivity. (c) Chromophobe renal cell carcinoma with negative CSF1R staining. 
focal immunoreactivity and two were negative for CSF1R staining. Of the 13 chromophobe renal cell carcinomas, 2 (15\%) showed occasional (focal) staining, with all remaining cases classified as negative (including the single case with RNA overexpression). One of the two unclassifiable renal cell carcinomas showed diffuse cytoplasmatic and membrane CSF1R immunoreactivity, whereas the other presented diffuse membrane CSF1R immunoreactivity. All 10 normal renal tissue samples displayed negative staining in proximal tubules and positive staining in distal and collecting tubules.

\section{CSF1R/PDGFRB Copy Number}

All 61 renal cell carcinomas were analyzed for CSF1R/PDGFRB copy number using a FISH probe targeting the two genes in 5q31 33 (control probe in 5p15; Table 1). Of the 41 clear cell renal cell carcinomas, 24 (59\%) had copy number gain of $C S F 1 R / P D G F R B$. Cell populations with relative $C S F 1 R / P D G F R B$ gain when compared with the control probe $(3: 2,4: 2$, or $6: 4)$ was observed in $29 \%$ of clear cell renal cell carcinomas, but $3: 3$ $(44 \%)$ and $4: 4(29 \%)$ signal patterns were also seen (Figure 3). Other chromosome 5 alterations were
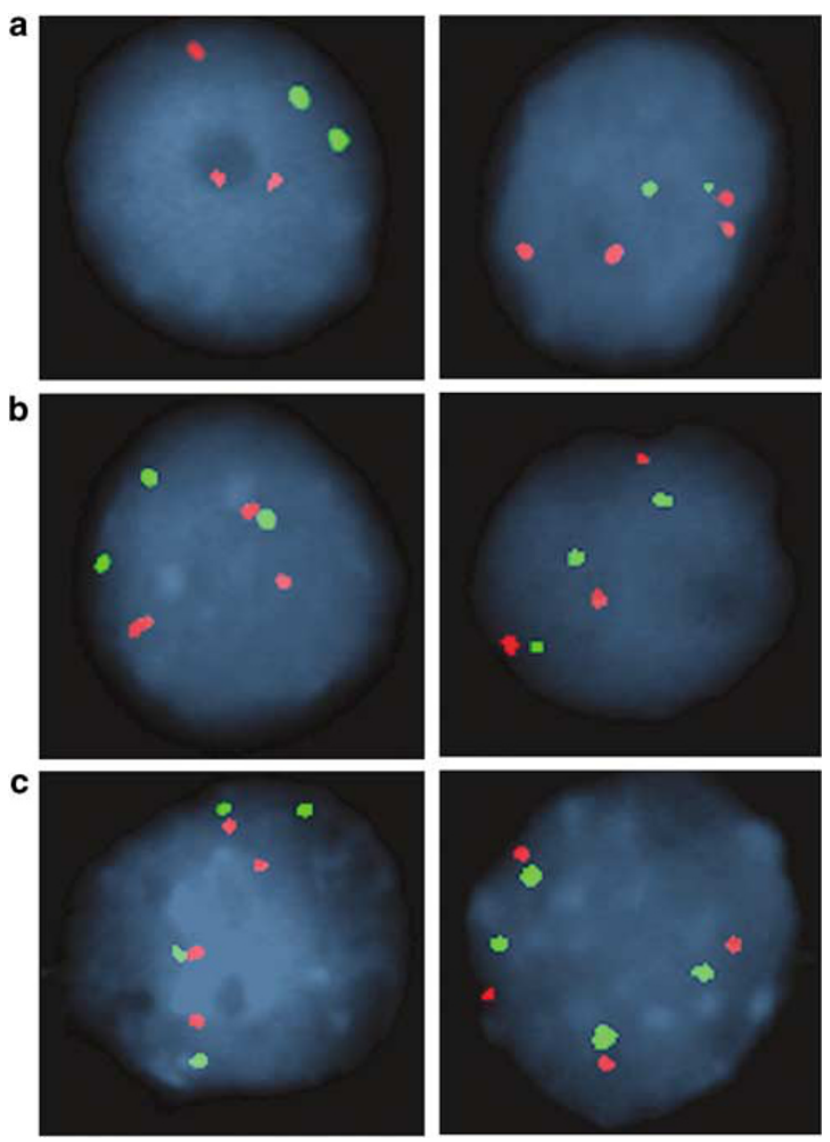

Figure $3 C S F 1 R / P D G F R B$ copy number changes in clear cell renal cell carcinomas evaluated by fluorescence in situ hybridization (CSF1R/PDGFRB, red; control probe, green). (a) Relative CSF1R/ PDGFRB copy number gain. (b) Trisomy. (c) Tetrasomy. observed more rarely. Of the 13 chromophobe renal cell carcinomas, $7(54 \%)$ had numerical changes of chromosome 5 , namely trisomy $(3: 3 ; 23 \%)$, tetrasomy $(4: 4 ; 46 \%)$, and monosomy $(1: 1 ; 8 \%) .5 q 31 \sim 33$ changes were not observed in papillary renal cell carcinomas. No statistically significant correlation

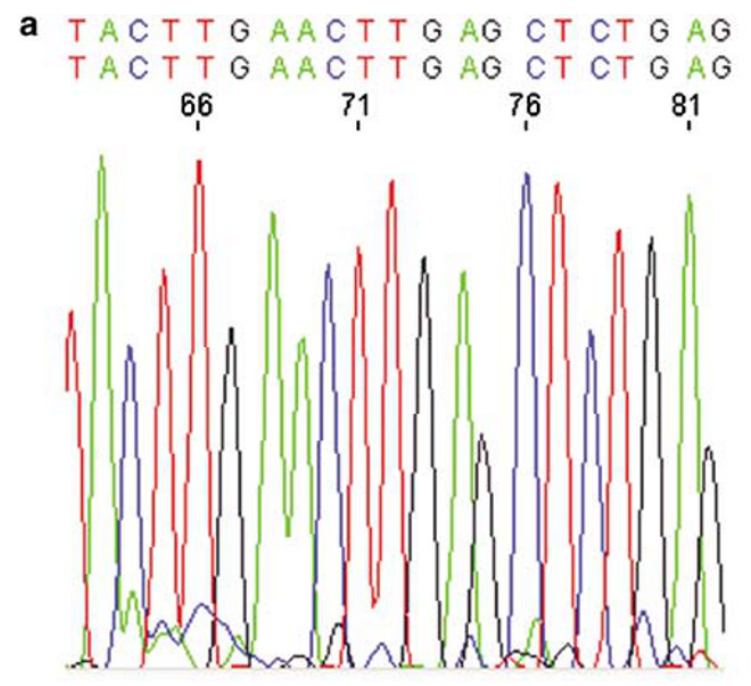

b $T A C T T G A A C T T G A G C T C T G A$ $T A C T T G A A C T T G A G C T C T G A$
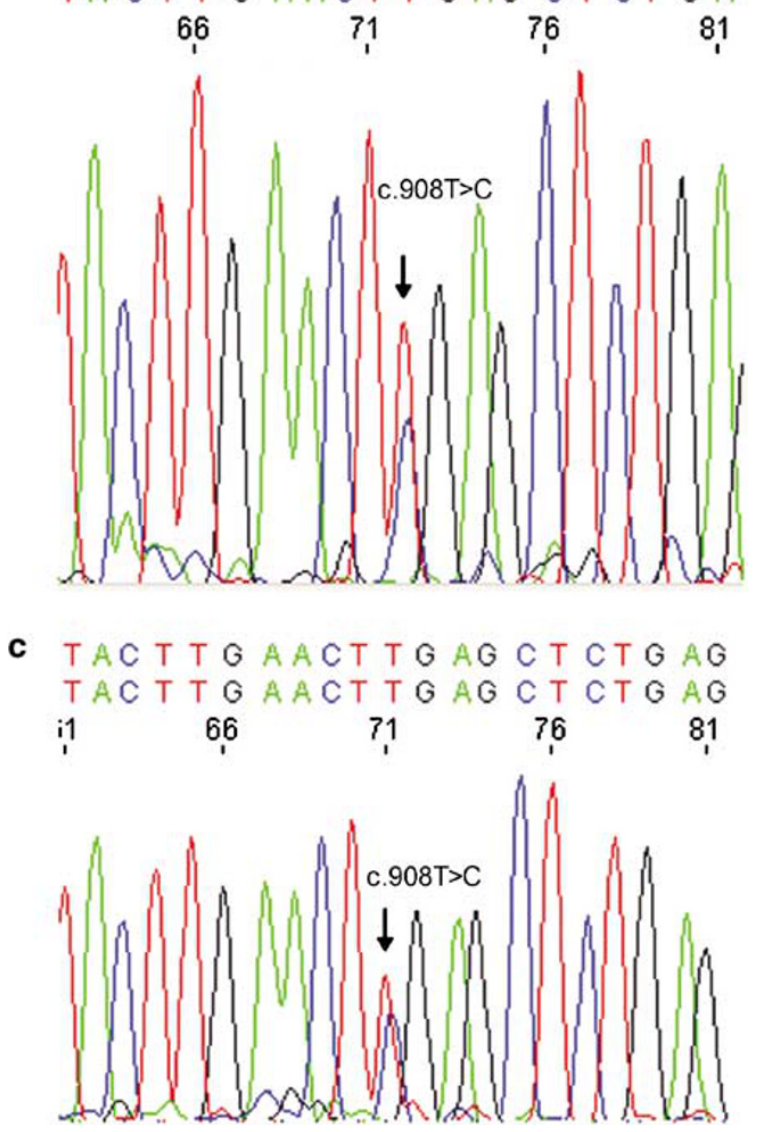

Figure 4 Sequencing analysis of exon 7 of $C S F 1 R$. (a) Wild type. (b) Tumor tissue showing the c.908T $>\mathrm{C}$ mutation. (c) The same mutation was found in the patient's blood sample, demonstrating its germline origin. 
was found between gene copy number and RNA expression.

\section{CSF1R Structural Changes}

All 41 clear cell renal cell carcinomas and 100 healthy blood donors were investigated for the presence of CSF1R mutations in exons 7 and 22 . Three genetic alterations were detected (Figure 4). A novel exon 7 mutation (c.908T $>$ C), which results in a leucine to serine substitution at codon 303, was detected in one patient in tumor tissue, in peripheral blood leukocytes, and in normal renal tissue. This novel mutation was absent in the 200 chromosomes from healthy blood donors. A second mutation, c. $12 \mathrm{C}>\mathrm{T}$, was found in the noncoding region of exon 22 ( $3^{\prime}$ UTR), was also detected in the patient's normal renal tissue, but not in the 200 chromosomes from healthy blood donors. Finally, the third change, c.2799T $>$ C, was detected in exon 22 in the tumor, in the patient's normal renal tissue, and in 2 of the 100 healthy blood donors, therefore, being classified as a polymorphism.

\section{Discussion}

Clear cell renal cell carcinoma is characterized by loss of genetic material from $3 p$, including the region 3p25 26 where the VHL gene is located. ${ }^{2}$ As germline $V H L$ mutations underlie the von Hippel-Lindau syndrome and VHL somatic mutations are found in most sporadic clear cell renal cell carcinomas, this gene is considered the most relevant target of the recurrent $3 p$ deletion seen in this tumor type. ${ }^{3,4}$ On the other hand, no target genes have been identified for the 5q22qter gain, the second most common chromosome aberration in clear cell renal cell carcinomas. We therefore tested whether two potential oncogenes mapping to that chromosomal region, CSF1R and PDGFRB, could be the relevant target genes of the recurrent $5 \mathrm{q}$ gain. We found that RNA overexpression of CSF1R was much more common than that of PDGFRB in clear cell renal cell carcinomas. On the contrary to what was observed for PDGFRB, the RNA expression of CSF1R was significantly higher in clear cell renal cell carcinomas than in normal kidney tissue samples. These findings agree with gene expression profile data showing $C S F 1 R$ as one of the genes more differentially expressed in renal cell carcinoma. ${ }^{17}$

The CSF1R RNA overexpression demonstrated in clear cell renal cell carcinomas was corroborated by protein overexpression observed by immunohistochemistry. Indeed, strong CSF1R membrane staining was present in most neoplastic cells of all cases of clear cell renal cell carcinomas, in clear contrast with other renal tumor types. These results indicate that CSF1R may be a useful immunohistochemical marker for the differential diagnosis of renal cell carcinoma. Indeed, the eosinophilic variant of chromophobe renal cell carcinoma is particularly difficult to distinguish from oncocytoma, whereas the typical variant of chromophobe renal cell carcinoma may closely resemble classical clear cell renal cell carcinoma. ${ }^{18}$ These difficulties are illustrated by the fact that one clear cell renal cell carcinoma of this series was reclassified as a chromophobe renal cell carcinoma by the pathologist after the tumor displayed a genetic pattern typical of the latter (Vieira J et al, in preparation). Interestingly, the staining pattern of this case was clearly different from that observed in all other clear cell renal cell carcinomas, indicating its potential usefulness for the differential diagnosis of clear cell renal cell carcinoma.

The immunohistochemical findings in nonneoplastic kidney tissue strengthen our proposal that CSF1R plays a role in clear cell renal cell carcinoma carcinogenesis. Positive staining was present in distal and collecting tubules, but not in the cells of the proximal tubule from which clear cell renal cell carcinoma presumably originate. Thus, the absence of immunoreactivity in cells of the proximal tubule and the presence of $C S F 1 R$ overexpression in the vast majority of clear cell renal cell carcinomas is compatible with the activation of an oncogene pathogenetically relevant for the development of this tumor subtype. On the other hand, the presence of positive staining in the cells of the collecting tubule, from which chromophobe renal cell carcinoma presumably originate, may explain the presence of focal CSF1R staining in some chromophobe renal cell carcinomas. The biological meaning of the diffuse cytoplasmatic and membrane CSF1R immunoreactivity observed in two of the five papillary carcinomas is not known, as this receptor tyrosine kinase is a membrane protein. However, it is noteworthy that papillary renal cell carcinoma also originates from proximal tubule and this may explain that a proportion of these tumors share some gene expression changes with clear cell renal cell carcinoma.

Proto-oncogene activation can result from chromosomal translocations, gene amplifications, or subtle intragenic mutations affecting crucial amino-acid residues that regulate the activity of the gene product. ${ }^{19,20}$ FISH analysis showed whole chromosomal gains and relative CSF1R/PDGFRB copy number gain, but no gene amplification. In particular, we confirmed that relative $5 q$ genomic gain is typical of clear cell renal cell carcinoma. However, no statistically significant association was observed between CSF1R/PDGFRB copy number and expression, indicating that copy number changes might contribute to, but do not fully explain, the $C S F 1 R$ overexpression seen in renal cell carcinomas. Another mechanism to activate proto-oncogenes is through point mutations. One CSF1R-silent single nucleotide polymorphism (SNP) and two novel mutations of unknown significance were identified in our panel of clear 
cell renal cell carcinomas. Silent SNPs have largely been assumed to exert no discernible effect on gene function or phenotype. However, some studies have provided evidence that synonymous SNPs can affect protein function by altering mRNA stability. ${ }^{21}$ One of the two mutations we found, results in a leucine to serine substitution at codon 303 (c.908T $>$ C). The same alteration was described by Ridge et $\mathrm{al}^{7}$ in codon 301 and seems to be associated with ligand independence and constitutive activation of the tyrosine kinase receptor. As the mutations we detected were present in the germline, one might conceive that they might confer hereditary predisposition to malignancy, but we have currently no evidence that this is the case in these three families.

Abnormally high $C S F 1 R$ expression has been associated with aggressive behavior and poor outcome in a variety of malignancies, including breast, ${ }^{22,23}$ endometrial, ${ }^{24,25}$ ovarian, ${ }^{26,27}$ and prostate cancers. ${ }^{28}$ The follow-up time in this series is still relatively short to allow a meaningful evaluation of the prognostic value of $C S F 1 R$ overexpression in renal cell carcinoma. The mechanisms whereby CSF1R overexpression might promote renal carcinogenesis may be similar to those of other neoplasms. Several studies indicate that autocrine and paracrine interaction of CSF1R and its ligand CSF1 may participate in the biology of breast cancer, being associated with tumor progression and metastasis. ${ }^{22,23,29}$ In ovarian cancer autocrine intracellular or extracellular interactions between CSF1R and CSF1 produced by the tumor cells are more relevant than paracrine effects of stromal CSF1. ${ }^{26,27}$ Concomitant expression of CSF1R and CSF1 was also observed in endometrial cancer cells and it is absent in the adjacent normal tissue. ${ }^{24,25}$ Finally, it has been shown in uterine cervical carcinomas that the CSF1/CSF1R-signaling pathway is involved in enhanced survival and invasion of cancer cells via an autocrine mechanism. ${ }^{30}$ Our finding of increased $C S F 1 R$ expression at both the mRNA and protein level in most clear cell renal cell carcinomas suggests that tumor cells may be hypersensitive even to normal CSF1 levels, presumably resulting in decreased apoptosis and increased ability to invade. Furthermore, our immunohistochemical data show that tumor cells, but not tumor-associated macrophages or stromal cells, are the main source of this receptor in clear cell renal cell carcinomas. Usually, papillary renal cell carcinomas show more macrophage infiltration than clear cell renal cell carcinomas, and these cells may also collaborate in a paracrine manner in tumor angiogenesis and invasion. ${ }^{31-33}$ Thus, the study of cytokine CSF1 expression separately in tumor and stromal cells is warranted to better understand its role together with CSF1R in renal tumorigenesis.

Sunitinib is currently approved as a second-line treatment of metastatic renal cell carcinoma in patients who have either not responded to or are not eligible to receive interleukin-2 therapy. ${ }^{34,35}$ Sunitinib targets selectively VEGF, KIT, FLT3, RET, PDGFRA, and PDGFRB ${ }^{36,37}$ and the fact that CSF1R shares structural and organizational homology with those receptor tyrosine kinases suggests a relevant role of CSF1R as a target of sunitinib in renal cell carcinoma patients. Furthermore, recent studies using hematopoietic colony assays demonstrated that imatinib targets CSF1R at therapeutic concentrations, ${ }^{38,39}$ further indicating that CSF1R may represent a future valuable therapeutic target of receptor tyrosine kinase drug inhibitors in renal cell carcinoma patients.

\section{Acknowledgement}

This work was supported in part by Fundação para a Ciência e Tecnologia (Grant Projecto Plurianual 2003/05) and by Liga Portuguesa Contra o Cancro.

\section{Disclosure/conflict of interest}

We have no conflict of interest to declare.

\section{References}

1 GLOBOCAN 2002. Cancer Incidence, Mortality and Prevalence Worldwide IARC Cancerbase No. 5, version 2.0 edn. IARC Press: Lyon, 2004.

2 Kovacs G, Akhtar M, Beckwith BJ, et al. The Heidelberg classification of renal cell tumours. J Pathol 1997;183:131-133.

3 Latif F, Tory K, Gnarra J, et al. Identification of the von Hippel-Lindau disease tumor suppressor gene. Science 1993;260:1317-1320.

4 Nickerson ML, Jaeger E, Shi $\mathrm{Y}$, et al. Improved identification of von Hippel-Lindau gene alterations in clear cell renal tumors. Clin Cancer Res 2008;14: 4726-4734.

5 Yang ZQ, Yoshida MA, Fukuda Y, et al. Molecular cytogenetic analysis of 17 renal cancer cell lines: increased copy number at 5q31-33 in cell lines from nonpapillary carcinomas. Jpn J Cancer Res 2000;91: 156-163.

6 Sapi E. The role of CSF-1 in normal physiology of mammary gland and breast cancer: an update. Exp Biol Med (Maywood) 2004;229:1-11.

7 Ridge SA, Worwood M, Oscier D, et al. FMS mutations in myelodysplastic, leukemic, and normal subjects. Proc Natl Acad Sci USA 1990;87:1377-1380.

8 McGlynn H, Baker AH, Padua RA. Biological consequences of a point mutation at codon 969 of the FMS gene. Leuk Res 1998;22:365-372.

9 Yang DH, Huang W, Cui J, et al. The relationship between point mutation and abnormal expression of cfms oncogene in hepatocellular carcinoma. Hepatobiliary Pancreat Dis Int 2004;3:86-89.

$10 \mathrm{Gu}$ TL, Mercher T, Tyner JW, et al. A novel fusion of RBM6 to CSF1R in acute megakaryoblastic leukemia. Blood 2007;110:323-333. 
11 Strefford JC, Stasevich I, Lane TM, et al. A combination of molecular cytogenetic analyses reveals complex genetic alterations in conventional renal cell carcinoma. Cancer Genet Cytogenet 2005;159:1-9.

12 Pearson H, Stirling D. DNA extraction from tissue. Methods Mol Biol 2003;226:33-34.

13 Bieche I, Laurendeau I, Tozlu S, et al. Quantitation of MYC gene expression in sporadic breast tumors with a real-time reverse transcription-PCR assay. Cancer Res 1999;59:2759-2765.

14 Casas S, Nagy B, Elonen E, et al. Aberrant expression of HOXA9, DEK, CBL and CSF1R in acute myeloid leukemia. Leuk Lymphoma 2003;44:1935-1941.

15 Wolff DJ, Bagg A, Cooley LD, et al. Guidance for fluorescence in situ hybridization testing in hematologic disorders. J Mol Diagn 2007;9:134-143.

16 Abu-Duhier FM, Goodeve AC, Care RS, et al. Mutational analysis of class III receptor tyrosine kinases (C-KIT, C-FMS, FLT3) in idiopathic myelofibrosis. Br J Haematol 2003;120:464-470.

17 Schuetz AN, Yin-Goen Q, Amin MB, et al. Molecular classification of renal tumors by gene expression profiling. J Mol Diagn 2005;7:206-218.

18 Liu L, Qian J, Singh H, et al. Immunohistochemical analysis of chromophobe renal cell carcinoma, renal oncocytoma, and clear cell carcinoma: an optimal and practical panel for differential diagnosis. Arch Pathol Lab Med 2007;131:1290-1297.

19 Hahn WC, Weinberg RA. Rules for making human tumor cells. N Engl J Med 2002;347:1593-1603.

20 Balmain A, Gray J, Ponder B. The genetics and genomics of cancer. Nat Genet 2003;33(Suppl):238-244.

21 Nackley AG, Shabalina SA, Tchivileva IE, et al. Human catechol-O-methyltransferase haplotypes modulate protein expression by altering mRNA secondary structure. Science 2006;314:1930-1933.

22 Kluger HM, Dolled-Filhart M, Rodov S, et al. Macrophage colony-stimulating factor-1 receptor expression is associated with poor outcome in breast cancer by large cohort tissue microarray analysis. Clin Cancer Res 2004;10:173-177.

23 Goswami S, Sahai E, Wyckoff JB, et al. Macrophages promote the invasion of breast carcinoma cells via a colony-stimulating factor-1/epidermal growth factor paracrine loop. Cancer Res 2005;65:5278-5283.

24 Baiocchi G, Kavanagh JJ, Talpaz M, et al. Expression of the macrophage colony-stimulating factor and its receptor in gynecologic malignancies. Cancer 1991; 67:990-996.

25 Smith HO, Anderson PS, Kuo DY, et al. The role of colony-stimulating factor 1 and its receptor in the etiopathogenesis of endometrial adenocarcinoma. Clin Cancer Res 1995;1:313-325.

26 Chambers SK, Kacinski BM, Ivins CM, et al. Overexpression of epithelial macrophage colony-stimulat- ing factor (CSF-1) and CSF-1 receptor: a poor prognostic factor in epithelial ovarian cancer, contrasted with a protective effect of stromal CSF-1. Clin Cancer Res 1997;3:999-1007.

27 Toy EP, Chambers JT, Kacinski BM, et al. The activated macrophage colony-stimulating factor (CSF-1) receptor as a predictor of poor outcome in advanced epithelial ovarian carcinoma. Gynecol Oncol 2001;80:194-200.

28 Ide H, Seligson DB, Memarzadeh S, et al. Expression of colony-stimulating factor 1 receptor during prostate development and prostate cancer progression. Proc Natl Acad Sci USA 2002;99:14404-14409.

29 Lin EY, Nguyen AV, Russell RG, et al. Colonystimulating factor 1 promotes progression of mammary tumors to malignancy. J Exp Med 2001;193:727-740.

30 Kirma N, Hammes LS, Liu YG, et al. Elevated expression of the oncogene $\mathrm{c}-\mathrm{fms}$ and its ligand, the macrophage colony-stimulating factor-1, in cervical cancer and the role of transforming growth factor-beta1 in inducing c-fms expression. Cancer Res 2007;67: 1918-1926.

31 del Vecchio MT, Lazzi S, Bruni A, et al. DNA ploidy pattern in papillary renal cell carcinoma. Correlation with clinicopathological parameters and survival. Pathol Res Pract 1998;194:325-333.

32 Hamada I, Kato M, Yamasaki T, et al. Clinical effects of tumor-associated macrophages and dendritic cells on renal cell carcinoma. Anticancer Res 2002;22: 4281-4284.

33 Douglass TG, Driggers L, Zhang JG, et al. Macrophage colony stimulating factor: not just for macrophages anymore! A gateway into complex biologies. Int Immunopharmacol 2008;8:1354-1376.

34 Motzer RJ, Rini BI, Bukowski RM, et al. Sunitinib in patients with metastatic renal cell carcinoma. JAMA 2006;295:2516-2524.

35 Motzer RJ, Hutson TE, Tomczak P, et al. Sunitinib versus interferon alfa in metastatic renal-cell carcinoma. N Engl J Med 2007;356:115-124.

36 Grimaldi AM, Guida T, D'Attino R, et al. Sunitinib: bridging present and future cancer treatment. Ann Oncol 2007;18(Suppl 6):vi31-vi34.

37 Motzer RJ, Michaelson MD, Redman BG, et al. Activity of SU11248, a multitargeted inhibitor of vascular endothelial growth factor receptor and platelet-derived growth factor receptor, in patients with metastatic renal cell carcinoma. J Clin Oncol 2006;24:16-24.

38 Dewar AL, Cambareri AC, Zannettino AC, et al. Macrophage colony-stimulating factor receptor c-fms is a novel target of imatinib. Blood 2005;105: 3127-3132.

39 Dewar AL, Zannettino AC, Hughes TP, et al. Inhibition of c-fms by imatinib: expanding the spectrum of treatment. Cell Cycle 2005;4:851-853. 